\title{
A Silurian age for the metasedimentary rocks of the Ekne Group, Trøndelag, Mid-Norwegian Caledonides: and inferences for a peri-Laurentian provenance
}

\author{
David Roberts ${ }^{1}$, Andrew Morton ${ }^{2,3} \&$ Dirk Frei $^{4}$ \\ ${ }^{1}$ Geological Survey of Norway, Post Box 6315 Torgarden, 7491 Trondheim, Norway. \\ ${ }^{2} \mathrm{HM}$ Research Associates, Giddanmu, St. Ishmaels, SA62 3TJ, UK. \\ ${ }^{3}$ CASP, West Building, Madingley Rise, Madingley Road, Cambridge, CB3 OUD, UK. \\ ${ }^{4}$ Department of Earth Sciences, University of Western Cape, Cape Town, South Africa. \\ E-mail corresponding author (David Roberts):David.Roberts@ngu.no
}

\begin{abstract}
$\mathrm{U}-\mathrm{Pb}$ analyses (LA-SF-ICP-MS) of detrital zircons from low-grade metasandstones, some tuffaceous, of the biostratigraphically-barren Ekne Group in the Støren Nappe of the Mid-Norwegian Caledonides have revealed that the sequence is almost entirely of Silurian age. The complete Ekne Group succession is about $2800 \mathrm{~m}$ thick and estimates of maximum depositional age based on the mean age of the youngest five zircon grains show an upward younging from 446.6 Ma at the base of the group to $432.9-427.2 \mathrm{Ma}$ in the upper half. In the sample close to the very top of the succession, a small number of zircons yield latest Silurian to earliest Devonian ages. Considering the inferred staging, recycling and catastrophic release of sediments into the basin during deposition, it is possible that the younger ages reflect genuine Early Devonian sediment input. All samples are dominated by Early Palaeozoic and notably Late Ordovician (Sandbian-Katian) zircon ages, with some peaks suggesting derivation from Taconian plutons occurring in different parts of Mid Norway. Some $40 \%$ of zircons in the sample from the base of the Ekne Group range in age from Mesoproterozoic to Palaeoarchaean. Bearing in mind the palaeogeography at the time, the Archaean grains are considered to have been recycled from older sandstones, with their original provenance most likely being the c. 3.65 Ga gneiss complexes in SW Greenland. As the Iapetus Ocean had closed by latest Ordovician time, by comparing the Ekne Group and other Silurian successions in Trøndelag with similar volcanosedimentary sequences in the northern Appalachians of USA and Canada, it is highly likely that the Ekne Group was deposited in a basin peripheral to the eastern margin of Laurentia during the Salinic orogenic cycle.
\end{abstract}

Keywords: Ekne Group, Silurian, detrital zircons, U-Pb analyses, Støren Nappe, Caledonides, Appalachians

Electronic Supplement: $U-P b$ zircon data

Received 15. March 2019/Accepted 9. October 2019/Published online 10. December 2019

\section{Introduction}

Over the last few decades, provenance studies and tectonic analysis of siliciclastic sedimentary rock successions have relied heavily on $\mathrm{U} / \mathrm{Pb}$ geochronology of detrital zircons. Such investigations, in many cases supported by other provenance indicators such as whole-rock and heavy-mineral geochemistry, and palaeocurrent data, have provided valuable information on the likely sources and ages of the zircons contained within the sedimentary load (e.g., Hallsworth et al., 2000; Garzanti et al., 2016 Fleming et al., 2016). In successions devoid of fossils, determining the maximum

Roberts, D., Morton, A. \& Frei, D. 2019: A Silurian age for the metasedimentary rocks of the Ekne Group, Trøndelag, Mid-Norwegian Caledonides: and inferences for a peri-Laurentian provenance.. Norwegian Journal of Geology 99, 583-595. https://dx.doi.org/10.17850/njg99-4-3. 


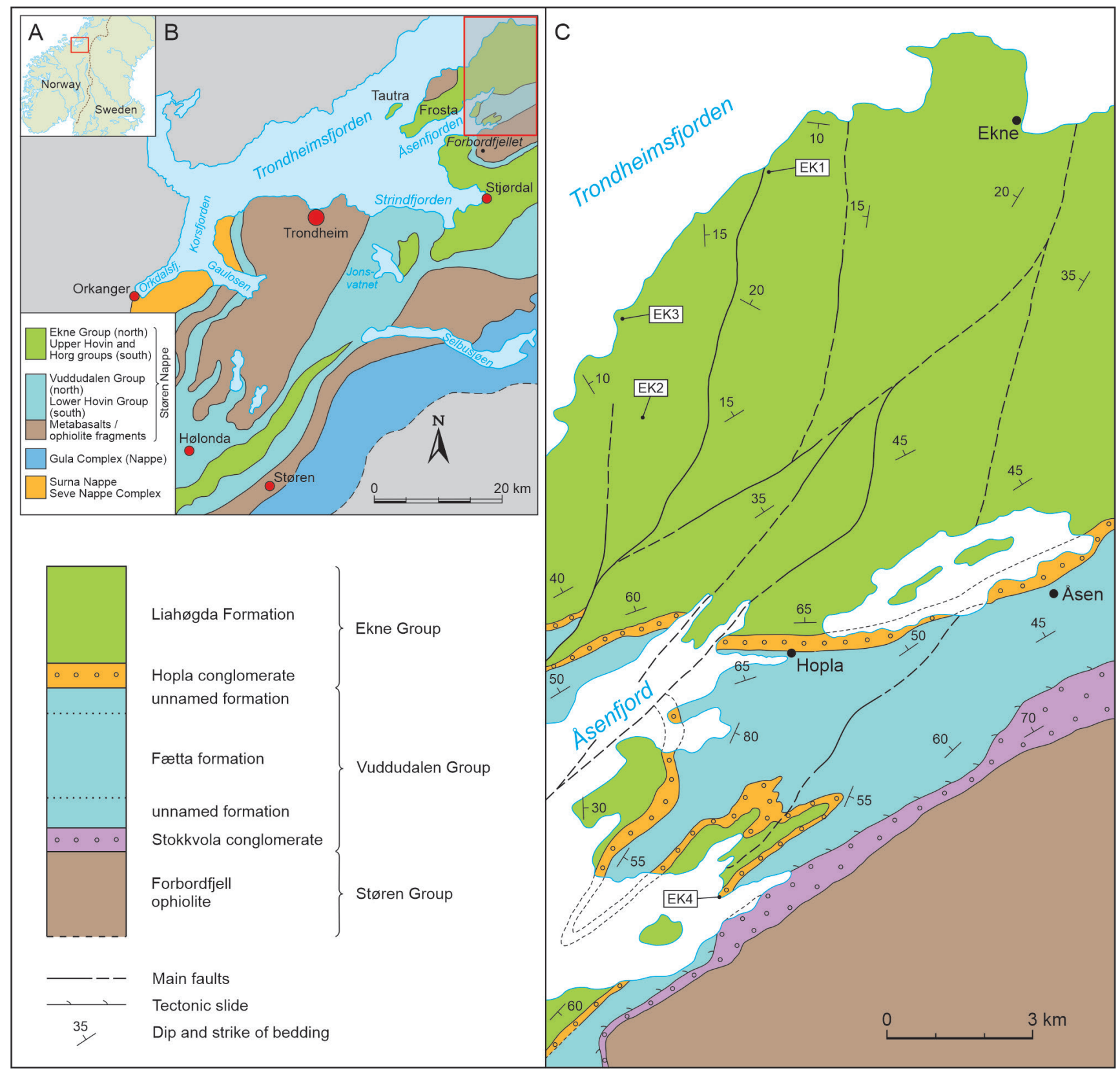

Figure 1. (A) Location map. (B) Outline geological map of part of the western Trondheim Region. The red rectangle in the top-right corner shows the area enlarged in the main map. (C) Simplified geological map of the Ekne-Åsenfjord area showing the locations of the four samples, EK1 to EK4.

depositional age can be of enormous help in constraining the geological history of the area and the particular rock complex under scrutiny. Zircon age data can be used to constrain maximum depositional age because evidently a deposit can be no older than its youngest detrital mineral constituent.

In this short contribution we present and interpret detrital zircon analytical data from a thick, biostratigraphically-barren sequence of sandstones with a felsic-tuffaceous component situated at the top of a Lower Palaeozoic, back-arc basinal succession in one of the nappes of the Mid-Norwegian Caledonides.

\section{Geological setting}

The Caledonide orogen of central Norway, represented mostly by the extensive Trondheim Nappe Complex, part of the Upper Allochthon, is especially well known on two accounts; namely, its prolific fauna in one particular area southwest of Trondheim, and secondly for the fragmented and dismembered ophiolite assemblages that lie at or close to the base of the Støren Nappe (Fig. 1B). Several geochronological studies have shown that the ocean-floor magmatic rocks of the ophiolite(s) range in age from Furongian to Tremadocian, within the timespan c. 497 to $480 \mathrm{Ma}$ (see references appended to table 
1 in Slagstad et al., 2014). Shortly after their generation in a suprasubduction-zone setting in the Iapetus Ocean, the ophiolites were obducted, deformed, weakly metamorphosed, uplifted and eroded, with their detritus forming a basal conglomerate to a thick, back-arc or marginal-basin, volcanosedimentary succession which has been inferred, but not satisfactorily proven, to extend up into the Silurian period (Vogt, 1945; Henriksen et al., 2018). A depositional model for the succession in the Ekne-Frosta area involved repeated events of longterm staging and reworking of sediments in near-shore areas before sudden, catastrophic release into the basin (Henriksen et al., 2018).

This largely Ordovician, greenschist-facies succession is rich in body fossils of Mid Ordovician (Dapingian to Darriwilian) age, notably in the Hølonda area just southwest of Trondheim (Fig. 1B). Thereafter, the faunal assemblages, which are of warm-water North American affinity, diminish in number and taxa during Sandbian and early Katian time. To the north of Trondheim, in the Frosta-Åsenfjord district (Fig. 1C), Early to Mid Katian fossils are recorded (Spjeldnæs, 1985; Tolmacheva \& Roberts, 2007), but no younger fauna has yet been found. Vogt (1945) suggested that the Upper Hovin and Horg groups of the Hølonda area could possibly be of Llandoverian age, based on finds of the graptolites Monograptus and Rastrites (Getz, 1890) in shales in the youngest sequence in another nappe in the easternmost part of the Trondheim Nappe Complex. Since the time of Vogt's (1945) classical work, the question of the age of the youngest rocks in the Hølonda area had remained unresolved. However, a provenance study by Gasser et al. (2016) in conjunction with U-Pb TIMS analyses of volcanic units has shown that sediments of the Horg Group extend up into the Wenlock epoch. Further U-Pb zircon dating work, in an area c. $50 \mathrm{~km}$ south of Hølonda, has shown that the youngest volcanosedimentary succession there is of Late Silurian age and possibly extending up into earliest Devonian time (Stokke et al., 2018).

The present contribution concerns the youngest Ekne Group in the Åsenfjord-Ekne area (Fig. 1C). This is a biostratigraphically-barren succession of greenschistfacies shales, siltstones, turbiditic graded-bedded sandstones and intercalated conglomerates with tuffaceous sandstones higher up. The base of the group is marked by the polymict Hopla conglomerate. The total thickness of the Ekne Group is estimated at 2800 m (Henriksen et al., 2018). In the Åsenfjord district, fragments of gastropods and corals of imprecise Mid to Late Ordovician age occur in metalimestones in higher parts of the subjacent Vuddudalen Group, which is otherwise characterised by deep-marine Nereites trace fossils (Roberts, 1969, 1984; Uchman et al., 2005). Details of the sedimentology and facies associations are given in Henriksen et al. (2018). In the present contribution, detrital zircons have been separated from four samples from the Ekne Group, from the basal Hopla conglomerate up to one of the youngest sandstones in the informally named Liahøgda formation (Figs. 1C \& 2), in an attempt to determine the maximum depositional age of the succession.

\section{$\mathrm{U}-\mathrm{Pb}$ zircon age determination}

$\mathrm{U}-\mathrm{Pb}$ age data were obtained by laser ablation, single collector, magnetic sectorfield, inductively coupled plasma mass spectrometry (LA-SF-ICP-MS) at the Central Analytical Facility of Stellenbosch University (South Africa), employing a Thermo Finnigan Element2 mass spectrometer coupled to an Australia Scientific Instruments Resolution S155 excimer laser ablation system. The zircon age data presented here were obtained by single spot analyses with a spot diameter of $30 \mu \mathrm{m}$ and a crater depth of approximately $15-20 \mu \mathrm{m}$, corresponding to an ablated zircon mass of approximately 150-200 ng. The zircon GJ-1 (Jackson et al., 2004) was used as primary calibration material to correct for instrumental mass bias and instrument drift. The laser induced element fractionation (LIEF) on ${ }^{206} \mathrm{~Pb} /{ }^{238} \mathrm{U}$ ratios was corrected using the intercept method. Common $\mathrm{Pb}$ was corrected using the background and ${ }^{202} \mathrm{Hg}$ interference corrected ${ }^{204} \mathrm{~Pb}$ signal and a model $\mathrm{Pb}$ composition (Stacey \& Kramers, 1975) at the projected age of the zircons. Gold traps are used in both $\mathrm{He}$ and $\mathrm{Ar}$ gas lines to reduce the $\mathrm{Hg}$ interference on ${ }^{204} \mathrm{~Pb}$. The methods employed for analysis and data processing are described in detail by Gerdes \& Zeh (2006) and Cornell et al. (2016). For quality control, the Plešovice (Sláma et al., 2008) and M127 (Nasdala et al., 2008; Mattinson, 2010) zircon reference materials were analysed, and the results were consistently in excellent agreement with the published ID-TIMS ages. Full analytical details and the results for all quality control materials analysed are reported in Table 1. Plotting of concordia diagrams (Fig. 3) was performed using Isoplot/ Ex 3.0 (Ludwig, 2003), with probability density distribution (PDD) and histogram diagrams (Figs. 4 \& 5) being generated by AgeDisplay (Sircombe, 2004). The threshold for using ${ }^{206} \mathrm{~Pb} /{ }^{238} \mathrm{U}$ vs ${ }^{207} \mathrm{~Pb} /{ }^{206} \mathrm{~Pb}$ ages plotted in PDD and histogram diagrams is $800 \mathrm{Ma}$. A concordance filter of 90 to $110 \%$ was applied to differentiate between concordant and discordant grains for display in the probability-density plots. Maximum depositional age determinations were made using the ${ }^{206} \mathrm{~Pb} /{ }^{238} \mathrm{U}$ ratios and ages.

Dickinson \& Gehrels (2009) proposed several criteria for constraining maximum depositional age using detrital zircon $\mathrm{U}-\mathrm{Pb}$ data. These include the youngest single grain age, the mean age of the youngest two or more grains that overlap in age at $1 \sigma$, and the mean age of the youngest three or more grains that overlap in age at $2 \sigma$. Of these, the most reliable is the mean age of the youngest three or more grains that overlap in age at $2 \sigma$ 

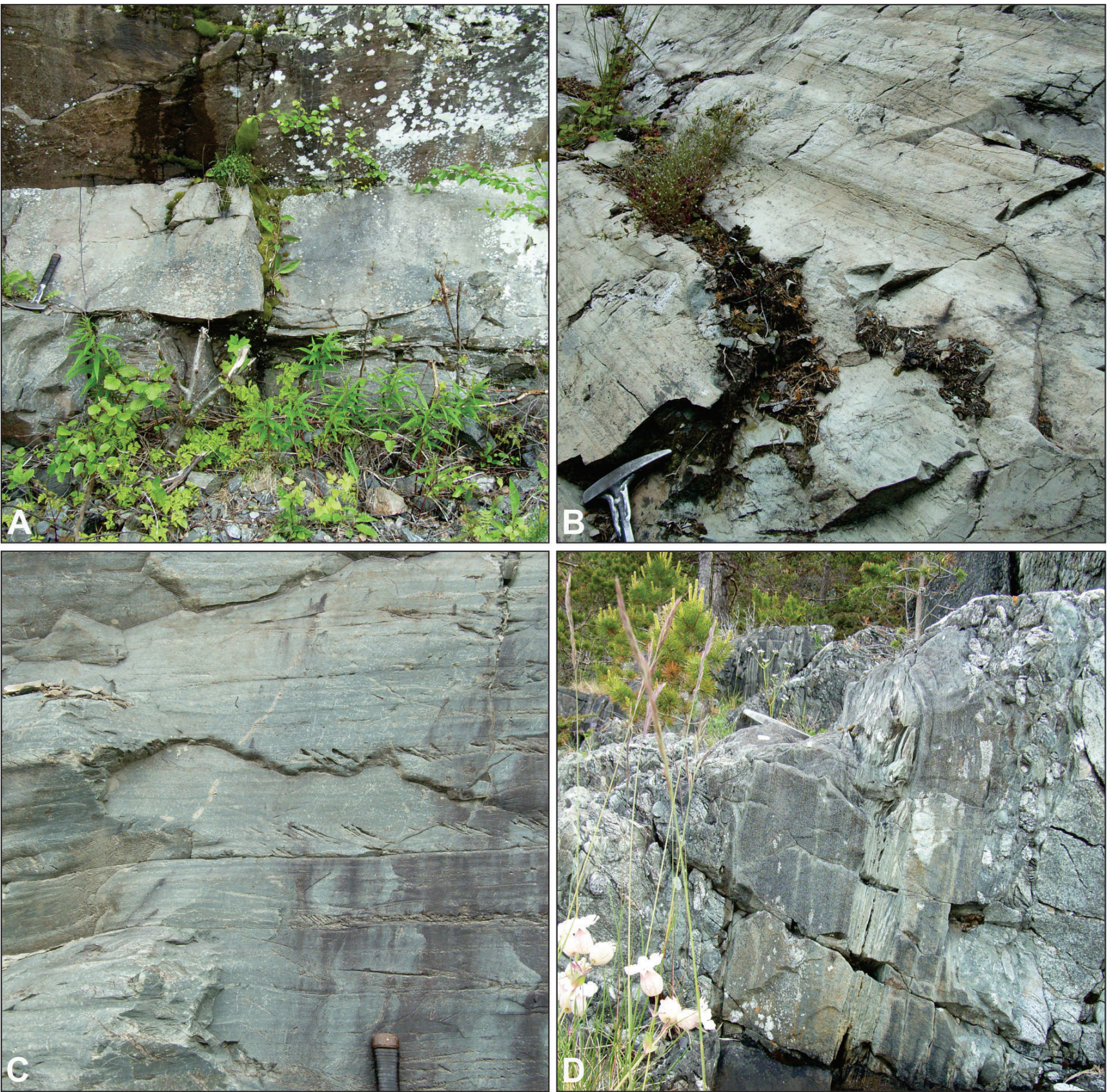

Figure 2. Field photos from the outcrops where the samples were collected. (A) Locality EK1. (B) Locality EK2. (C) Locality EK3. (D) Locality EK4.

(Dickinson \& Gehrels, 2009). We discuss all three criteria in this contribution, with the additional provisos that only zircons with $95-105 \%$ concordance are considered, thus eliminating grains nearest to discordance and making the assessment of maximum depositional ages more robust. We also take the mean age of the youngest five zircons that overlap in age at $2 \sigma$ in order to be consistent with the equivalent study on the succession discussed by Stokke et al. (2018).

\section{Sample locations and descriptions}

The zircons analysed in this study come from four samples of sandstones collected from different parts of the Ekne Group succession. The numbering of the samples starts in what is adjudged to be a unit close to the very top of the Liahøgda Formation succession (EK1) near the core of a late-stage open syncline (Roberts, 1985). Samples EK2 and EK3 were taken approximately midway through the thick succession, whilst sample EK4 comes from a sandstone bed within the basal Hopla conglomerate formation (Fig. 1C). The samples were 

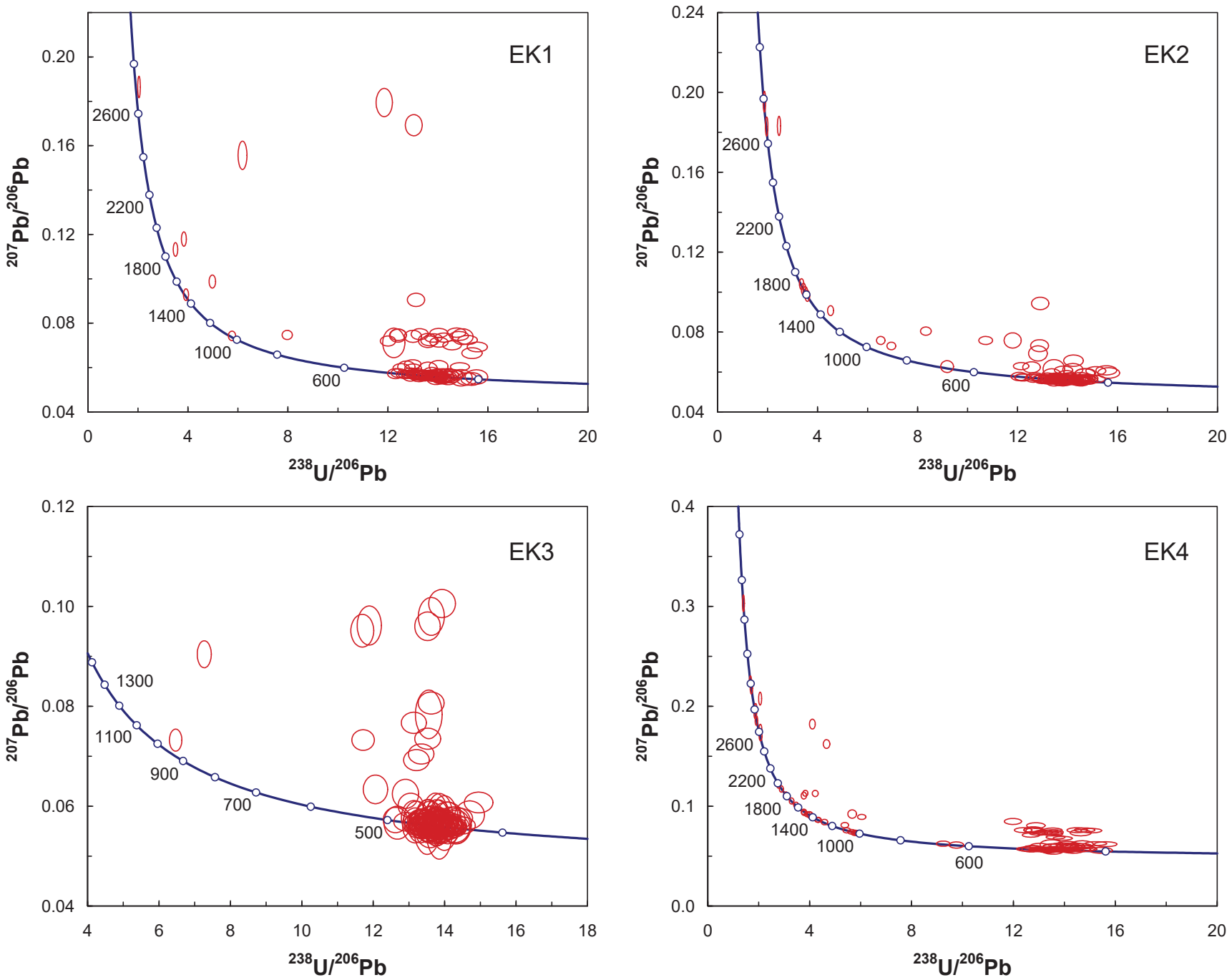

Figure 3. $U-P b$ isotopic compositions of zircons in samples EK1-4 plotted on Tera-Wasserburg concordia diagrams.

all of roughly double-fist size. All the sampling sites are situated on the 1:50,000 topographic map-sheet 'Frosta' $1622-2$, UTM zone 32 V, blue grid WGS84, and the given map coordinates for each site thus follow this system.

EK1. Grid reference 59570 706410. Locality in a road-cut along a minor road c. $7 \mathrm{~km}$ west of Ekne, at about $500 \mathrm{~m}$ northeast of Kristivika (Fig. 2A).

EK2. Grid reference 59340 705920. Locality in a long road-cut c. $200 \mathrm{~m}$ east of the small lake Skardtjønna (Fig. 2B).

EK3. Grid reference 59295 706090. Outcrop along a gravel road c. $100 \mathrm{~m}$ south of the reception office to the ‘Åsholmen camping’ site (Fig. 2C).

EK4. Grid reference 59475704940 . Locality at the rocky promontory Blekkpynten, just a couple of metres west of small concrete steps leading along the shoreline (Fig. 2D).

\section{Results}

\section{Sample EK4}

The oldest sample in the study, EK4, comes from a sandstone bed within the basal Hopla conglomerate formation. A relatively high proportion of the zircons in this sample yielded discordant $\mathrm{U}-\mathrm{Pb}$ ages, which might be due to either residual common $\mathrm{Pb}$ (undercorrection for common $\mathrm{Pb}$ contents) or $\mathrm{Pb}$ loss related to crystal damage caused by alpha-recoil or hydrothermal/thermal resetting. Most of the discordant grains in this sample plot in a near-linear array just above concordia on the Tera-Wasserburg diagram (Fig. 3) that resembles a discordia trend. Furthermore, zircons with similar low ${ }^{206} \mathrm{~Pb} /{ }^{204} \mathrm{~Pb}$ ratios show a variable degree of concordance (from highly concordant to highly discordant). Additionally, the common $\mathrm{Pb}(\mathrm{cPb})$ correction for the secondary quality control standard Plešovice, which is known to contain significant amounts of 
Table 1. LA-SF-ICP-MS U-Th-Pb dating methodology at CAF, Stellenbosch University

\begin{tabular}{|c|c|}
\hline \multicolumn{2}{|l|}{ Laboratory \& Sample Preparation } \\
\hline Laboratory name & Central Analytical Facility, Stellenbosch University \\
\hline Sample type / mineral & Detrital zircons \\
\hline Sample preparation & Conventional mineral separation, 1 inch resin mount, $1 \mu \mathrm{m}$ polish to finish \\
\hline Imaging & CL, LEO $1430 \mathrm{VP}, 10 \mathrm{nA}, 15 \mathrm{~mm}$ working distance \\
\hline \multicolumn{2}{|l|}{ Laser ablation system } \\
\hline Make, Model \& type & ESI/New Wave Research, UP213, Nd:YAG \\
\hline Ablation cell \& volume & Custom build low volume cell, volume c. $3 \mathrm{~cm}^{3}$ \\
\hline Laser wavelength & $213 \mathrm{~nm}$ \\
\hline Pulse width & $3 \mathrm{~ns}$ \\
\hline Fluence & $2.5 \mathrm{~J} / \mathrm{cm}^{-2}$ \\
\hline Repetition rate & $10 \mathrm{~Hz}$ \\
\hline Spot size & $30 \mu \mathrm{m}$ \\
\hline Sampling mode / pattern & $30 \mu \mathrm{m}$ single spot analyses \\
\hline Carrier gas & $100 \% \mathrm{He}$, Ar make-up gas combined using a T-connector close to sample cell \\
\hline $\begin{array}{l}\text { Pre-ablation laser warm-up } \\
\text { (background collection) }\end{array}$ & 40 seconds \\
\hline Ablation duration & 20 seconds \\
\hline Wash-out delay & 30 seconds \\
\hline Cell carrier gas flow & $0.3 \mathrm{l} / \mathrm{min} \mathrm{He}$ \\
\hline \multicolumn{2}{|l|}{ ICP-MS Instrument } \\
\hline Make, Model \& type & Thermo Finnigan Element2 single collector HR-SF-ICP-MS \\
\hline Sample introduction & Via conventional tubing \\
\hline RF power & $1100 \mathrm{~W}$ \\
\hline Make-up gas flow & 1.0 l/min $\mathrm{Ar}$ \\
\hline Detection system & Single collector secondary electron multiplier \\
\hline Masses measured & $202,204,206,207,208,232,233,235,238$ \\
\hline Integration time per peak & $4 \mathrm{~ms}$ \\
\hline Total integration time per reading & Approx. $1 \mathrm{sec}$ \\
\hline Sensitivity & $20000 \mathrm{cps} / \mathrm{ppm} \mathrm{Pb}$ \\
\hline Dead time & $16 \mathrm{~ns}$ \\
\hline
\end{tabular}

\section{Data Processing}

\begin{tabular}{|c|c|}
\hline Gas blank & 40 second on-peak \\
\hline Calibration strategy & $\begin{array}{l}\text { GJ-1 used as primary reference material, Plešovice and M127 used as secondary reference } \\
\text { material (Quality Control) }\end{array}$ \\
\hline Reference Material info & $\begin{array}{l}\text { M127 (Nasdala et al., 2008; Mattinson, 2010); Plešovice (Slama et al., 2008); } \\
\text { GJ-1 (Jackson et al., 2004) }\end{array}$ \\
\hline $\begin{array}{l}\text { Data processing package used / } \\
\text { Correction for LIEF }\end{array}$ & $\begin{array}{l}\text { In-house spreadsheet data processing using intercept method for laser induced elemental } \\
\text { fractionation (LIEF) correction }\end{array}$ \\
\hline Mass discrimination & $\begin{array}{l}\text { Standard-sample bracketing with } 207 \mathrm{~Pb} / 206 \mathrm{~Pb} \text { and } 206 \mathrm{~Pb} / 238 \mathrm{U} \text { normalised to reference } \\
\text { material GJ-1 }\end{array}$ \\
\hline $\begin{array}{l}\text { Common-Pb correction, composition } \\
\text { and uncertainty }\end{array}$ & $\begin{array}{l}\text { 204-method, Stacey \& Kramers (1975) composition at the projected age of the mineral, } \\
5 \% \text { uncertainty assigned }\end{array}$ \\
\hline Uncertainty level \& propagation & $\begin{array}{l}\text { Ages are quoted at } 2 \text { sigma absolute, propagation is by quadratic addition. Reproducibility } \\
\text { and age uncertainty of reference material and common- } \mathrm{Pb} \text { composition uncertainty are } \\
\text { propagated. }\end{array}$ \\
\hline Quality control / Validation & $\begin{array}{l}\text { Plešovice: } \mathrm{Wtd} \text { ave } 206 \mathrm{~Pb} / 238 \mathrm{U} \text { age }=337 \pm 4(2 \mathrm{SD}, \mathrm{MSWD}=0.2) \\
\text { M127: Wtd ave } 206 \mathrm{~Pb} / 238 \mathrm{U} \text { age }=520 \pm 5(2 \mathrm{SD}, \mathrm{MSWD}=0.8)\end{array}$ \\
\hline
\end{tabular}



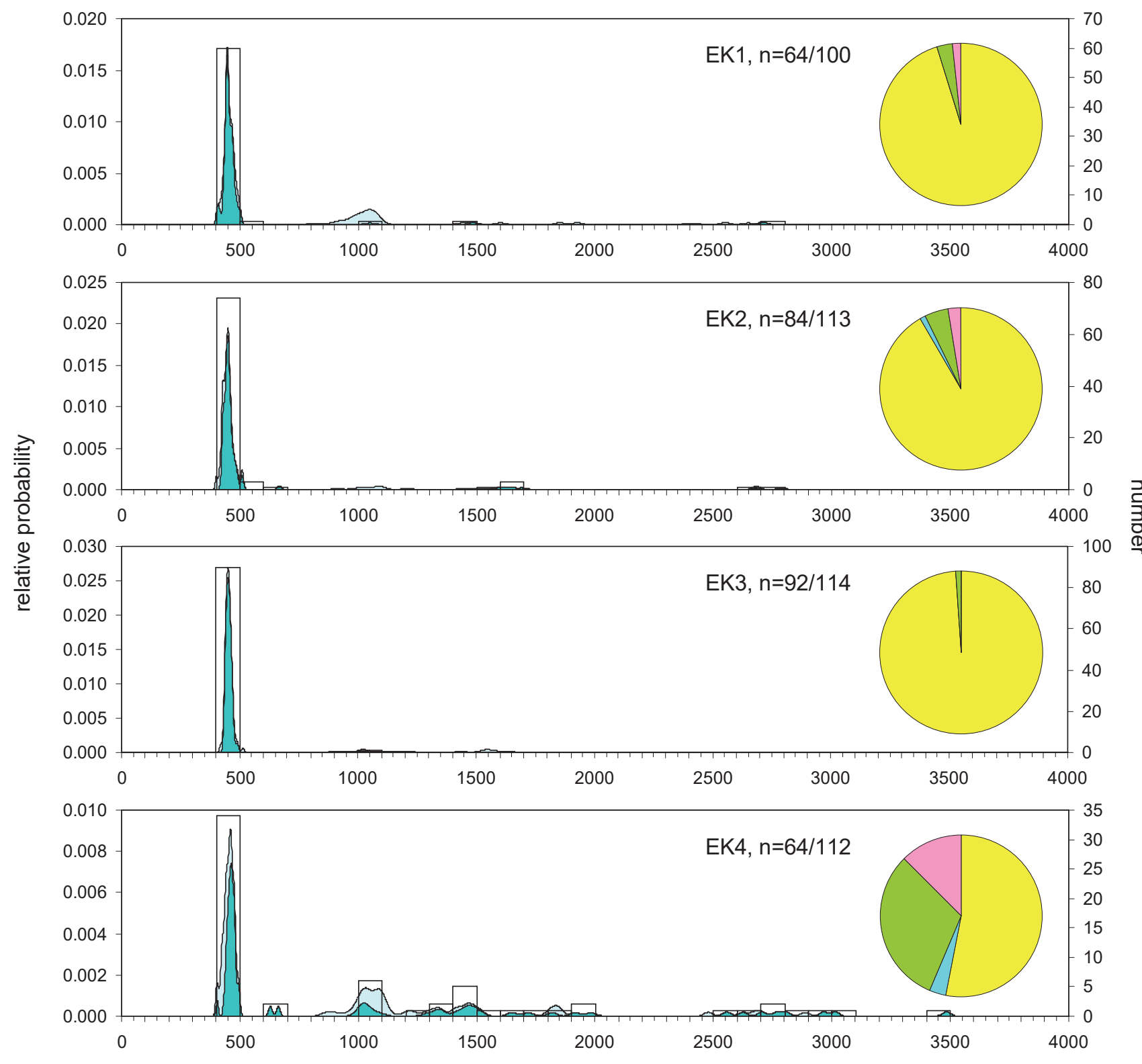

Age (Ma)

$\square$ Early Palaeozoic $\square$ Neoproterozoic $\square$ Meso- and Palaeoproterozoic $\square$ Archaean

Figure 4. Detrital zircon ages in samples EK1-4 displayed as probability-density plots. ' $n$ ' $=$ number of zircons with $<10 \%$ discordance in the total zircon population. Dark blue areas are zircons with $<10 \%$ discordance, pale blue areas are zircons with $>10 \%$ discordance. Pie charts show relative abundance of Early Palaeozoic, Neoproterozoic, Meso- and Palaeoproterozoic and Archaean zircons.

$\mathrm{cPb}$, yielded highly concordant analyses, which argues against undercorrection of $\mathrm{cPb}$ (e.g., due to insufficient interference correction of $\mathrm{Hg}$ in the carrier gas). We therefore argue that the observed discordance is mainly due to $\mathrm{Pb}$ loss.

The majority of the zircons with $<10 \%$ discordance (64 of the 112 analysed grains, $53 \%$ of the population) form a single peak in the Early Palaeozoic (Fig. 4). However, the spectrum also includes a relatively high proportion of Proterozoic and Archaean zircons. Palaeo- to Mesoproterozoic zircons (1013-1982 Ma) comprise $31 \%$ of the near-concordant population, with Archaean zircons (2556-3486 Ma) forming a further $12 \%$. The Proterozoic zircons are wide-ranging in age but appear to cluster mainly at c. $1000-1100 \mathrm{Ma}$ and $1300-1500 \mathrm{Ma}$, whereas the Archaean component has no obvious age structure. There are also two late Neoproterozoic zircons (c. $629 \mathrm{Ma}$, c. $662 \mathrm{Ma}$ ).

The Palaeozoic zircons form a single relatively broad group between c. $434 \mathrm{Ma}$ and c. $492 \mathrm{Ma}$ (Fig. 5). There 


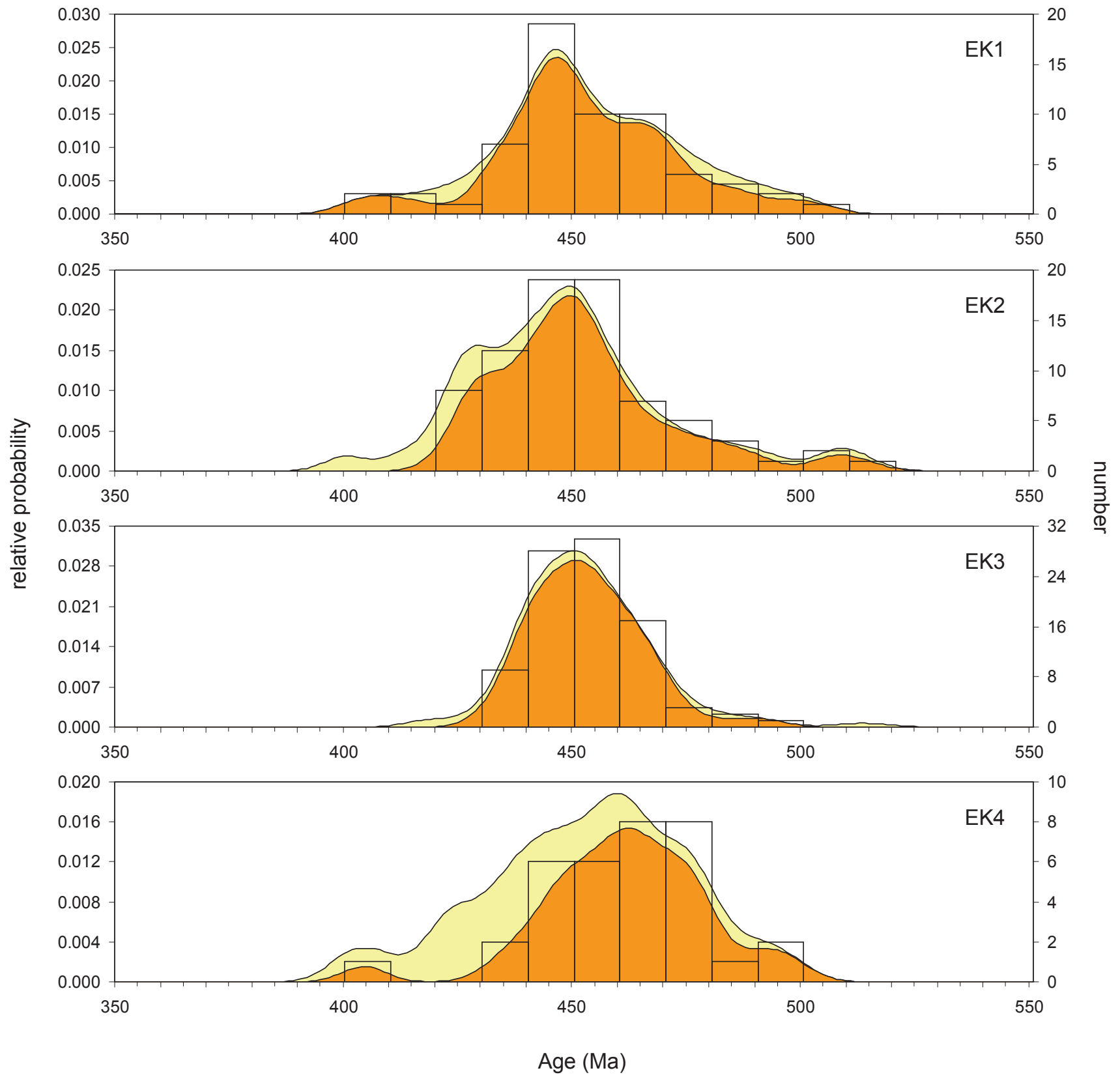

Figure 5. Expansion of the Phanerozoic part of the zircon age spectra for samples EK1-4. Orange areas are zircons with $<10 \%$ discordance, pale yellow areas are zircons with $>10 \%$ discordance.

is a single younger zircon dated as c. $405 \mathrm{Ma}$, but this is only $91 \%$ concordant and the age is considered to be anomalously young, probably due to $\mathrm{Pb}$-loss. Excluding this single outlier, the Palaeozoic zircons are dominated by a large group peaking at $462 \mathrm{Ma}$, with a minor subsidiary group peaking at $492 \mathrm{Ma}$.

Estimates of maximum depositional age using the Dickinson \& Gehrels (2009) criteria are as follows: youngest single grain $=434.3 \mathrm{Ma}$, mean age of the youngest 2 zircons overlapping at $1 \sigma=438.2 \mathrm{Ma}$, and mean age of the youngest 5 zircons overlapping at $2 \sigma=$ 446.6 Ma.

\section{Sample EK3}

Sample EK3, which is from a tuffaceous sandstone bed approximately midway through the succession, has a much higher proportion of zircons with near-concordant $\mathrm{U}-\mathrm{Pb}$ ages compared with EK4 (Fig. 3). Virtually all the zircons with $<10 \%$ discordance $(n=92 / 114$, Fig. 3) yielded Early Palaeozoic ages, with only one nearconcordant Proterozoic grain and a total absence of the Archaean. The Palaeozoic zircons are dominated by a large group peaking at $451 \mathrm{Ma}$, with a minor subsidiary group peaking at $489 \mathrm{Ma}$. 
Estimates of maximum depositional age using the Dickinson \& Gehrels (2009) criteria are as follows: youngest single grain $=434.8 \mathrm{Ma}$, mean age of the youngest 2 zircons overlapping at $1 \sigma=435.6 \mathrm{Ma}$, and mean age of the youngest 5 zircons overlapping at $2 \sigma=$ 437.0 Ma.

\section{Sample EK2}

Sample EK2, a tuffaceous sandstone, is also from roughly midway through the succession though slightly higher up than sample EK3. Similarly to EK3, most of the zircon analyses are near-concordant (Fig. 3), with 84 of the 113 analysed grains having $<10 \%$ discordance. Of the 84 near-concordant zircons, the great majority (92\%) is Early Palaeozoic (Fig. 4), but there is one Neoproterozoic grain (664 Ma), four Mesoproterozoic grains (1588-1697 $\mathrm{Ma})$ and two Neoarchaean grains (2680 Ma, $2788 \mathrm{Ma}$ ).

The Early Palaeozoic zircon spectrum (Fig. 5) is dominated by a group peaking at $450 \mathrm{Ma}$ (in EK4 at $460 \mathrm{Ma}$ ), with a subsidiary peak at $509 \mathrm{Ma}$. There is a suggestion of a younger peak at c. $430 \mathrm{Ma}$ manifested by a shoulder on the 450 Ma peak (Fig. 5).

Estimates of maximum depositional age using the Dickinson \& Gehrels (2009) criteria are as follows: youngest single grain $=424.5 \mathrm{Ma}$, mean age of the youngest 2 zircons overlapping at $1 \sigma=425.8 \mathrm{Ma}$, and mean age of the youngest 5 zircons overlapping at $2 \sigma=$ 427.2 Ma.

\section{Sample EK1}

Sample EK1 is from a tuffaceous sandstone bed considered to be close to the top of the Liahøgda formation. A relatively high proportion of the zircons in this sample yielded discordant $\mathrm{U}-\mathrm{Pb}$ ages, owing to the abundance of common $\mathrm{Pb}$ (as identified by low ${ }^{206} \mathrm{~Pb} /{ }^{204} \mathrm{~Pb}$ ratios). Similar to sample EK4, most of the discordant grains in this sample plot in a near-linear array just above concordia on the Tera-Wasserburg diagram (Fig. 3), and zircons with similar low ${ }^{206} \mathrm{~Pb} /{ }^{204} \mathrm{~Pb}$ ratios show a variable degree of concordance (from highly concordant to highly discordant). Again, we therefore argue that the observed discordance is most likely caused by $\mathrm{Pb}$ loss.

Most of the zircons with $<10 \%$ discordance (64 of the 100 analysed grains) form a single peak in the Early Palaeozoic, which forms 95\% of the near-concordant population (Fig. 3). In addition, there is minor representation of the Proterozoic (1049 Ma, $1485 \mathrm{Ma}$ ) and Archaean (2711 Ma). The Early Palaeozoic zircons form a bimodal population with peaks at $447 \mathrm{Ma}$ and $464 \mathrm{Ma}$ (Fig. 4), together with four zircons that yielded younger apparent ages. The ages of these grains are 402.0 \pm 4.7 Ma, 406.9 \pm 4.6 Ma, 411.7 $\pm 4.7 \mathrm{Ma}$ and $418.1 \pm 5.1$ $\mathrm{Ma}$. The youngest of these can be rejected on the basis of a concordance measurement of only $90.7 \%$, but the other three are closer to concordia (97.5-101.5\% concordant). Using the Dickinson \& Gehrels (2009) criteria, therefore, gives the youngest single grain $=406.9 \mathrm{Ma}$, and mean age of the youngest 2 zircons overlapping at $1 \sigma=409.3 \mathrm{Ma}$. However, the more reliable criterion (mean age of the youngest 5 zircons overlapping at $2 \sigma$ ) gives a significantly older maximum depositional age of 432.9 Ma.

\section{Discussion}

On the basis of the most reliable of the criteria proposed by Dickinson \& Gehrels (2009), maximum depositional ages determined for the Ekne Group succession show an upward younging, from 446.6 Ma (Late Ordovician) at the base (sample EK4), to 437.0 Ma (Llandovery, Early Silurian) and 427.2 Ma (Wenlock, Mid Silurian) in the middle parts of the succession (samples EK3 and EK2, respectively). The sample from near the top of the succession (EK1) has a conservative maximum depositional age of 432.9 Ma (Wenlock, Mid Silurian). The youngest of these ages $(427.2 \mathrm{Ma})$ is closely comparable to the maximum depositional age of $\mathrm{c}$. $430 \mathrm{Ma}$ inferred for the Horg Group in the Hølonda area (Gasser et al., 2016), and that of c. $427 \mathrm{Ma}$ for the sandstone succession at Dugurdsknappen c. $50 \mathrm{~km}$ south of Hølonda (Stokke et al., 2018). Although there are a small number of zircons yielding latest Silurian and earliest Devonian ages in sample EK1, additional confirmatory analyses would be required before proposing that deposition of the Ekne Group genuinely extended into the earliest Devonian. Nevertheless, considering the inferred multiple pulses of staging and recycling of sediments in this tectonically active basin then a Devonian input cannot be discounted.

Three of the four analysed samples are overwhelmingly dominated by Early Palaeozoic (Mid to Late Ordovician) zircon ages, but over $40 \%$ of the zircons in the basal sample (EK4) are much older (Proterozoic and Archaean) (Fig. 4). Given the wide diversity of ages concerned, these zircons are interpreted as being recycled from pre-existing sandstones. Their most likely origin would be sediments from older successions in the Caledonian nappes, but the abundance of Archaean zircons is somewhat surprising. Current information suggests that zircons of this age are comparatively scarce throughout the Lower, Middle, Upper and Uppermost allochthons (Bingen \& Solli, 2009; Slagstad \& Kirkland, 2017 and references therein). However, relatively few data have been published from the nappes of the Upper Allochthon, to which the Ekne Group succession belongs. We also note that Archaean zircons are relatively common in metasandstones in the Lower Nappe of the 
Helgeland Nappe Complex (Uppermost Allochthon) in the Bindal area, Nordland county, as are Meso- and Palaeoproterozoic zircons between c. $1000 \mathrm{Ma}$ and c. $1900 \mathrm{Ma}$ (Barnes et al., 2007). Recycling of zircons from sandstones with similar age spectra could account for the Precambrian component of the detrital zircon population found in the basal Ekne Group.

The EK4 Hopla sample and also a sandstone from Hovin, near Hølonda, have yielded zircons of Eoarchaean to Palaeoarchaean age. The Hovin zircon (Forskning, 2010) was considered to have been derived from SW Greenland, probably by recycling, where granitoid rocks in the Itsaq Gneiss Complex are of latest Eoarchaean to Palaeoarchaean $(3.65 \mathrm{Ga})$ age (Nutman et al., 1999, 2000; Whitehouse et al., 1999). Here, it is important to remember that the prolific Mid to Late Ordovician body fossils in the Hølonda area are of North American provinciality, as are the few fossils found in the Vuddudalen Group, below the Ekne Group. Thus, sedimentation and volcanic activity at this time (Bruton \& Bockelie, 1980; Grenne \& Roberts, 1998) and in the succeeding Silurian period, in the nappes now exposed in Mid Norway, were occurring in a location peripheral to the eastern seaboard of Laurentia. The basin was conceivably close to southeasternmost palaeoGreenland (Domeier \& Torsvik, 2014; Domeier, 2016), possibly even involving the proximal margin of the Ganderian microcontinent which had already accreted to Laurentia by Mid Silurian time (van Staal et al., 2009, 2012; Fyffe et al., 2011; Wilson et al., 2017). Comparable arc-magmatic and basin-depositional activity at this time is recorded not only in the northern Appalachians and Newfoundland but also in the Irish Caledonides (Waldron et al., 2014).

The dominance of Early Palaeozoic zircon ages in the dataset is of interest with regard to possible sources for the various peaks. The weak 490-480 Ma signature registered in all samples is clearly denoting a derivation of these zircon grains from fairly local ophiolitic assemblages (Fig. 5). The source or sources for the peak of c.460 Ma in the oldest sample, EK4, is open to speculation, since we have no palaeocurrent flow indicators in the sandstones. Calc-alkaline arc plutons with ages of 465-459 Ma occur in the Gjersvik Nappe and Helgeland Nappe Complex some $150 \mathrm{~km}$ north of the Ekne area (Nordgulen et al., 1993; Meyer et al., 2003; Barnes et al., 2007). Similar plutons U-Pb-dated to $460 \mathrm{Ma}$ also occur in the Smøla-Hitra Batholith on islands and the mainland in coastal Trøndelag, as well as on the northwestern side of Trondheimsfjorden c. $40 \mathrm{~km}$ northwest of Ekne (Tucker et al., 2004). All these plutons are considered to be parts of Taconian batholiths, akin in age and geochemistry to those in the northern Appalachians and southernmost East Greenland (Higgins et al., 2004; Roberts et al., 2007; Hollocher et al., 2016). In samples EK1-3, zircon grains spike predominantly at c. $450 \mathrm{Ma}$ (Fig. 5) and may derive from rhyolites in the Hovin-Hølonda district dated at around this age (D.Gasser, pers. comm. 2019). Subsidiary zircon peaks or shoulders at $430 \mathrm{Ma}$ in some samples could signify a source from widespread, $438-430 \mathrm{Ma}$, pre-collisional plutons in the Gula Complex (Dunning \& Grenne, 2000; Nilsen et al., 2003, 2007).

Following from the above considerations, the lithological successions of the Vuddudalen and Ekne groups should be compared with volcanosedimentary successions of the northern Appalachians and Irish Caledonides, where there are several reports of Silurian, calc-alkaline, bimodal volcanic and felsic-tuffaceous metasedimentary rocks (Whalen et al., 2006; Fyffe et al., 2011; Pinán Llamos \& Hepburn, 2013; Wilson et al., 2015, 2017; Kay et al., 2017). Such a comparison may be significant and lead to a better understanding of how Iapetus closurerelated tectonic elements can be correlated along the length of the orogen. While it is not a topic of the current publication, it is one that will generate much interesting research among future generations of CaledonianAppalachian geologists. One may speculate, for example, that the unconformity marking the 'Ekne Disturbance' of Vogt (1936), i.e., at the base of the Ekne Group, may equate with the unconformity marking the inception of the Salinic orogenic cycle, in Katian time, in the northern Appalachians (e.g., Wilson et al., 2017). This is a distinct possibility, timewise; but alternatively, it may relate to the third phase of the Taconian orogeny (van Staal et al., 2009). In the Dugurdsknappen area, Stokke et al. (2018) have described isoclinal folding and an associated metamorphic phase that preceded an unconformity at the base of a post- $427 \mathrm{Ma}$ (Ludlow) volcanosedimentary succession. This tectonometamorphic episode, which has yet to be dated, may be equivalent to the main collisional phase of regional orogenesis in the northern Appalachians (van Staal et al., 2009, 2012; Wilson et al., 2017). The fact that this pre-427 Ma folding and metamorphism is not recognised in the Ekne Group succession may well indicate that the basinal successions in the Ekne, Hølonda-Støren and Dugurdsknappen districts are possibly derived from separate areas, subbasins or even disparate terranes in the AppalachianCaledonian collage, each with their own depositional, volcanic and deformational histories. The Ekne Group succession is thus in some ways reminiscent of deposition in a successor basin, in this case synScandian and located at a high level in the Støren Nappe. Significant variations in basinal, volcanic and structural developments along the strike of the orogen have indeed been recorded in many of the publications cited above.

Broadly speaking, the main phase of the Salinic orogeny in the Appalachians is temporally equivalent to the Scandian orogeny in the Scandinavian Caledonides. In both regions, the later stages of these orogenies are characterised by extensional faulting and fairly flat-lying foliations resulting from vertical shortening concomitant with orogenic collapse during the Early Devonian period 
(e.g., Roberts, 1967, 1968; Hossack, 1984; van Staal \& de Roo, 1995; Fossen, 2010; Wilson et al., 2017; Stokke et al., 2018).

Volcanosedimentary successions of Silurian age, specifically in the Upper Allochthon, are known from western and southwestern Norway, based on finds of body fossils (Skjerlie, 1974; Thon, 1985). In central Norway, graptolites of Llandovery age have been described from the eastern part of the Trondheim Region (Getz, 1890). Thus, the recently documented geochronological proof of the existence of Silurian sedimentary rocks in the Hølonda (Gasser et al., 2016) and Dugurdsknappen (Stokke et al., 2018) areas, together with the results from our own study, adds to the fact that sedimentation in certain basins extended up into Mid or Late Silurian times, and conceivably into the Early Devonian period.

\section{Conclusions}

$\mathrm{U}-\mathrm{Pb}$ age data from detrital zircons obtained by LA-SFICP mass spectrometry on four samples of sandstones from the barren Ekne Group in the Caledonides of Mid Norway include the following main results:

1 Estimates of maximum depositional age-based on the mean age of the five youngest grains-range from 446.6 Ma in a sandstone bed (sample EK4) in the basal Hopla conglomerate to 432.9 to $427.2 \mathrm{Ma}$ in variably tuffaceous sandstones (EK1-3) in the upper half of the group. The bulk of the c. $2.8 \mathrm{~km}$ thick Ekne Group is thus of Silurian age.

2 Early Paleozoic zircons dominate all four samples. These comprise $92-99 \%$ of the $<10 \%$ discordant zircons in the three stratigraphically highest samples (EK1-3), with the lowest sample (EK4) containing $53 \%$. The majority of the Early Palaeozoic zircons are Late Ordovician (Sandbian-Katian), but in sample EK4, the population peak is at $462 \mathrm{Ma}$ (Darriwilian), with a subsidiary group at $492 \mathrm{Ma}$ (Late Cambrian), the latter likely to have derived from ophiolites. Sample EK2 also contains a few Cambrian grains. Sources for the c. $460 \mathrm{Ma}$ zircons are thought to be plutons from Taconian batholiths exposed in different parts of Mid Norway.

3 About $40 \%$ of zircons in EK4 at the base of the Ekne Group range in age from Mesoproterozoic to Palaeoarchaean. The Archaean grains (oldest at 3486 $\mathrm{Ma}$ ) are considered to have been recycled from older sediments, and to have originally been sourced from known Palaeoarchaean gneiss complexes in Southwest Greenland.

4 The basin hosting the Ekne Group was evidently located in a terrane peripheral to the eastern seaboard of Laurentia, with deposition involving a volcanic arc source likely to have occurred during the protracted Salinic orogenic cycle that is recognised in many parts of the northern Appalachians and its Caledonian equivalent in the British Isles.

Acknowledgements. We thank Cees van Staal and Sverre Henriksen for comments and suggestions on an early version of the manuscript. DF acknowledges support from the DSI-NRF Centre of Excellence for Integrated Mineral and Energy Resource Analysis (CIMERA). Helpful suggestions and constructive comments by the reviewers, Deta Gasser and Chris Kirkland, were conducive to final improvements in the text and figures. Irene Lundqvist helped with production of Figs. $1 \& 2$.

\section{References}

Barnes, C.G., Frost, C.D., Yoshinobu, A.S., McArthur, K., Barnes, M.A., Allen, C.M., Nordgulen, Ø. \& Prestvik, T. 2007: Timing of sedimentation, metamorphism, and plutonism in the Helgeland Nappe Complex, north-central Norwegian Caledonides. Geosphere 3,683-703. https://doi.org/10.1130/GES00138.1.

Bingen, B. \& Solli, A. 2009: Geochronology of magmatism in the Caledonian and Sveconorwegian belts of Baltica: synopsis for detrital zircon provenance studies. Norwegian Journal of Geology $89,267-290$.

Bruton, D.L. \& Bockelie, J.F. 1980: Geology and paleontology of the Hølonda area, western Norway, a fragment of North America? Virginia Polytechnic Institute Department of Geological Sciences, Memoir 2, 41-47.

Cornell, D., Zack, T., Andersen, T., Corfu, F., Frei, D. \& van Schijndel, V. 2016: Th-U-Pb zircon geochronology of the Palaeoproterozoic Hartley Formation porphyry by six methods, with age uncertainty approaching $1 \mathrm{Ma}$. South African Journal of Geology 119, 473-494. https://doi.org/10.2113/gssajg.119.3.473.

Dickinson, W.R. \& Gehrels, G.E. 2009: Use of U-Pb ages of detrital zircons to infer maximum depositional ages of strata: A test against a Colorado Plateau Mesozoic database. Earth and Planetary Science Letters 288, 115-125. https://doi.org/10.1016/j.epsl.2009.09.013.

Domeier, M. 2016: A plate tectonic scenario for the Iapetus and Rheic oceans. Gondwana Research 36, 275-295. https://doi.org/10.1016/j. gr.2015.08.003.

Domeier, M. \& Torsvik, T.H. 2014: Plate tectonics in the Late Paleozoic, Geoscience Frontiers 5, 303-350. https://doi.org/10.1016/j.gsf.2014.01.002.

Dunning, G.R. \& Grenne, T. 2000: U-Pb age dating and paleotectonic significance of trondhjemite from the type locality in the Central Norwegian Caledonides. Norges geologiske undersøkelse Bulletin 437, 57-65.

Fleming, E., Flowerdew, M.J., Smyth, H., Scott, R.A., Morton, A.C., Omma, J.E., Frei, D. \& Whitehouse, M.J. 2016: Provenance of Triassic sandstones on the southwest Barents Shelf and the implication for sediment dispersal patterns in northwest Pangaea. Marine and Petroleum Geology 78, 516-535.

https://doi.org/10.1016/j.marpetgeo.2016.10.005.

Forskning, 2010: 3635 millioner år - Norges eldste sandkorn. https:// Forskning.no/geofag/2010/04/3635-millioner-ar-norges-eldstesandkorn

Fossen, H. 2010: Extensional tectonics in the North Atlantic Caledonides: a regional view. Geological Society, London, Special Publications 335, 767-793. https://doi.org/10.1144/SP335.31. 
Frei, D. \& Gerdes, A. 2009: Precise and accurate in-situ U-Pb dating of zircon with high sample throughput by automated LA-SF-ICPMS. Chemical Geology 261, 261-270. https://doi.org/10.1016/j.chemgeo.2008.07.025.

Fyffe, L.R., Johnson, S.C. \& van Staal, C.R. 2011: A review of Proterozoic to Early Paleozoic lithotectonic terranes in the northeastern Appalachian orogen of New Brunswick, Canada, and their tectonic evolution during Penebscot, Taconic, Salinic, and Acadian orogenesis. Atlantic Geology 47, 211-242. https://doi.org/10.4138/atlgeol.2011.010.

Garzanti, E., Vermeesch, P., Andò, S., Lustrino, M., Padoan, M. \& Vezzoli, G. 2016: Ultra-long distance littoral transport of Orange sand and provenance of the Skeleton Coast Erg (Namibia). Marine Geology 357, 25-36. https://doi.org/10.1016/j.margeo.2014.07.005.

Gasser, D., Grenne, T., Corfu, F. \& Augland, L.E. 2016: Characterization of depositional age and structure of sedimentary successions by $\mathrm{U}_{-}$ $\mathrm{Pb}$ TIMS and LA-ICP-MS dating of volcanic horizons and detrital zircons: an example from the western Trondheim Nappe Complex, Scandinavian Caledonides. Abstract and poster, EGU General Assembly, 17-22 April, Vienna.

Gerdes, A. \& Zeh, A. 2006: Combined U-Pb and Hf isotope LA(MC)-ICP-MS analyses of detrital zircons: Comparison with SHRIMP and new constraints for the provenance and age of an Armorican metasediment in Central Germany. Earth and Planetary Science Letters 249, 47-61. https://doi.org/10.1016/j.epsl.2006.06.039.

Getz, A. 1890: Graptolitførende skiferzone i det Trondhjemske. Nyt Magazin for Naturvidenskaberne 31, 41-42.

Grenne, T. \& Roberts, D. 1998: The Hølonda Porphyrites, Norwegian Caledonides: geochemistry and tectonic setting of Early-Mid Ordovician shoshonitic volcanism. Journal of the Geological Society 155, 131-142. https://doi.org/10.1144/gsjgs.155.1.0131.

Hallsworth, C.R., Morton, A.C., Claoué-Long, J.C. \& Fanning, C.M 2000: Carboniferous sand provenance in the Pennine Basin, UK: constraints from heavy mineral and SHRIMP zircon age data. Sedimentary Geology 137, 147-185.

https://doi.org/10.1016/S0037-0738(00)00153-6.

Henriksen, S., Roberts, D. \& Pedersen, P.-A. 2018: Turbidite and conglomerate successions in an Ordovician back-arc basin, MidNorwegian Caledonides: a result of long-term staging followed by catastrophic release of sediments. Norwegian Journal of Geology 98, 141-164. https://doi.org/10.17850/njg98-1-09.

Higgins, A.K., Elvevold, S., Escher, J.C., Frederiksen, A.K., Gilotti, J.A., Henriksen, N., Jepsen, H.F., Jones, K.A., Kalsbeek, F., Kinny, P.D., Leslie, A.G., Smith, M.P., Thrane, K. \& Watt, G.R. 2004: The foreland-propagating thrust architecture of the East Greenland Caledonides $72^{\circ}-75^{\circ} \mathrm{N}$. Journal of the Geological Society of London 161, 1009-1026. https://doi.org/10.1144/0016-764903-141.

Hollocher, K., Robinson, P., Seaman, K. \& Walsh, E. 2016: Ordovician - Early Silurian intrusive rocks in the northwest part of the Upper Allochthon, Mid-Norway: plutons of an Iapetus volcanic arc complex. American Journal of Science 316, 925-980. https://doi.org/10.2475/10.2016.01.

Hossack, J.R. 1984: The geometry of listric normal faults in the Devonian basins of Sunnfjord, W. Norway. Journal of the Geological Society, London 141, 629-637. https://doi.org/10.1144/gsjgs.141.4.0629.

Jackson, S., Pearson, N., Griffin, W. \& Belousova, E. 2004: The application of laser ablation-inductively coupled plasma-mass spectrometry to in situ U-Pb zircon geochronology. Chemical Geology 211, 47-69. https://doi.org/10.1016/j.chemgeo.2004.06.017.

Kay, A., Hepburn, J.C., Kuiper, Y.D. \& Baxter, E.F. 2017: Geochemical evidence for a Ganderian arc/back-arc remnant in the Nashoba terrane, SE New England, USA. American Journal of Science 317, 413-448. https://doi.org/10.2475/04.2017.01.
Ludwig, K.R. 2003: Isoplot/Ex version 3. A geochronological toolkit for Microsoft Excel. Berkeley Geochronlogy Center, Special Publication 4, 1-71.

Mattinson, J.M. 2010: Analysis of the relative decay constants of ${ }^{235} \mathrm{U}$ and ${ }^{238} \mathrm{U}$ by multi-step CA-TIMS measurements of closed-system natural zircon samples. Chemical Geology 275, 186-198. https://doi.org/10.1016/j.chemgeo.2010.05.007.

Meyer, G.B., Grenne, T. \& Pedersen, R.B. 2003: Age and tectonic setting of the Nesåa Batholith: implications for Ordovician arc development in the Caledonides of Central Norway. Geological Magazine 140, 573-594. https://doi.org/10.1017/S0016756803008069.

Nasdala, L., Hofmeister, W., Norberg, N., Mattinson, J.M., Corfu, F., Dörr, W., Kamo, S.L., Kennedy, A.K., Kronz, A., Reiners, P.W., Frei, D., Košler, J., Wan, Y., Götze, J., Häger, T., Kröner, A. \& Valley, J.W. 2008: Zircon M257 - a homogeneous natural reference material for the ion microprobe $\mathrm{U}-\mathrm{Pb}$ analysis of zircon. Geostandards and Geoanalytical Research 32,247-265. https://doi.org/10.1111/j.1751-908X.2008.00914.x.

Nilsen, O., Sundvoll, B., Roberts, D. \& Corfu, F. 2003: U-Pb geochronology and geochemistry of trondhjemites and a norite pluton from the SW Trondheim Region, Central Norwegian Caledonides. Norges geologiske undersøkelse Bulletin 441, 5-16.

Nilsen, O., Corfu, F. \& Roberts, D. 2007: Silurian gabbro-dioritetrondhjemite plutons in the Trondheim Nappe Complex, Caledonides, Norway: petrology and $\mathrm{U}-\mathrm{Pb}$ geochronology. Norwegian Journal of Geology 87, 329-342.

Nordgulen, Ø., Bickford, M.E., Nissen, A.L. \& Wortman, G.L. 1993: U$\mathrm{Pb}$ zircon ages from the Bindal Batholith, and the tectonic history of the Helgeland Nappe Complex, Scandinavian Caledonides. Journal of the Geological Society of London 150,771-783. https://doi.org/10.1144/gsigs.150.4.0771.

Nutman, A.P., Bennett, V.C., Friend, C.R.L. \& Nutman, M.D. 1999: Meta-igneous (non-gneissic) tonalites and quartz-diorites from an extensive ca. $3800 \mathrm{Ma}$ terrain south of the Isua supracrustal belt, southern West Greenland: constraints on early crust formation. Contributions to Mineralogy and Petrology 137, 364-388. https://doi.org/10.1007/s004100050556.

Nutman, A.P., Bennett, V.C., Friend, C.R.L. \& McGregor, V.R. 2000: The early Archaean Itsaq Gneiss Complex of southern West Greenland: the importance of field observations in interpreting age and isotopic constraints for early terrestrial evolution. Geochimica et Cosmochimica Acta 64, 3035-3060. https://doi.org/10.1016/S0016-7037(99)00431-7.

Pinán Llamas, A. \& Hepburn, J.C. 2013: Geochemistry of SilurianDevonian volcanic rocks in the Coastal Volcanic belt, MachiasEastport area, Maine: evidence for a pre-Acadian arc. Geological Society of America Bulletin 125, 1930-1942. https://doi.org/10.1130/B30776.1.

Roberts, D. 1967: Structural observations from the KopperåRiksgrense area and discussion of the tectonics of Stjørdalen and the NE Trondheim Region. Norges geologiske undersøkelse 245, 64-122.

Roberts, D. 1968: Tectonic features of an area NE of Hegra, NordTrøndelag, and their regional significance. Norges geologiske undersøkelse 255, 10-20.

Roberts, D. 1969: Trace fossils from the Hovin Groups, NordTrøndelag, and their bathymetric significance. Norges geologiske undersøkelse Bulletin 258, 228-236.

Roberts, D. 1984: Nereites from the Ordovician rocks of the eastern Trondheimsfjord area, Central Norwegian Caledonides. Norges geologiske undersøkelse Bulletin 396, 43-45.

Roberts, D. 1985: Frosta. Berggrunnsgeologisk kart 1622 II, 1:50,000 foreløpig utgave (preliminary edition). Norges geologiske undersøkelse. 
Roberts, D., Nordgulen, Ø. \& Melezhik, V. 2007: The Uppermost Allochthon in the Scandinavian Caledonides: from a Laurentian ancestry through Taconian orogeny to Scandian crustal growth on Baltica. Geological Society of America Memoir 200, 357-377. https://doi.org/10.1130/2007.1200(18).

Sircombe, K.N. 2004: AgeDisplay: an EXCEL workbook to evaluate and display univariate geochronological data using binned frequency histograms and probability density distributions. Computers \& Geosciences 30, 21-31.

https://doi.org/10.1016/j.cageo.2003.09.006.

Skjerlie, F. 1974: The Lower Palaeozoic sequence of the Stavfjord district, Sunnfjord. Norges geologiske undersøkelse Bulletin 302, $1-32$.

Slagstad, T. \& Kirkland, C.L. 2017: The use of detrital zircon data in terrane analysis: a nonunique answer to provenance and tectonostratigraphic position in the Scandinavian Caledonides. Lithosphere 9, 1002-1011. https://doi.org/10.1130/L663.1.

Slagstad, T., Pin, C., Roberts, D., Kirkland, C.L., Grenne, T., Dunning, G., Sauer, S. \& Andersen, T. 2014: Tectonomagmatic evolution of the Early Ordovician suprasubduction-zone ophiolites of the Trondheim Region, Mid-Norwegian Caledonides. In Corfu, F., Gasser, D. \& Chew, D.M. (eds.): New perspectives on the Caledonides of Scandinavia and related areas, Geological Society, London, Special Publications 390, pp. 541-561.

https://doi.org/10.1144/SP390.11.

Sláma, J., Košler, J., Condon, D.J., Crowley, J.L., Gerdes, A., Hanchar, J.M., Horstwood, M.S.A., Morris, G.A., Nasdala, L., Norberg, N., Schaltegger, U., Schoene, B., Tubrett, M.N. \& Whitehouse, M.J. 2008: Plešovice zircon - a new natural reference material for $\mathrm{U}-\mathrm{Pb}$ and Hf isotopic microanalysis. Chemical Geology 249, 1-35.

https://doi.org/10.1016/j.chemgeo.2007.11.005.

Spjeldnæs, N. 1985: Biostratigraphy of the Scandinavian Caledonides. In Gee, D.G. \& Sturt, B.A. (eds.): The Caledonide orogen Scandinavia and related areas, John Wiley \& Sons, Chichester, pp. 317-329.

Stacey, J.S. \& Kramers, J.D. 1975: Approximation of terrestrial lead isotope evolution by a two-stage model. Earth and Planetary Science Letters 26, 207-221. https://doi.org/10.1016/0012-821X(75)90088-6.

Stokke, E.W., Gasser, D., Dalslåen, B.H. \& Grenne, T. 2018: Tectonic evolution of syn- to late-orogenic sedimentary-volcanic basins in the central Norwegian Caledonides. Journal of the Geological Society 175, 605-618. https://doi.org/10.1144/jgs2017-091.

Thon, A. 1985: Late Ordovician and Early Silurian cover sequences to the west Norwegian ophiolite fragments: stratigraphy and structural evolution. In Gee, D.G. \& Sturt, B.A. (eds.) The Caledonide Orogen -- Scandinavia and related areas. John Wiley \& Sons Ltd., Chichester, 407-415.

Tolmacheva, T.J. \& Roberts, D. 2007: New data on Upper Ordovician conodonts from the Trondheim Region, Central Norwegian Caledonides. Norges geologiske undersøkelse Bulletin 447, 5-15.

Tucker, R.D., Robinson, P., Solli, A., Gee, D.G., Thorsnes, T., Nordgulen, Ø., Krogh, T.E. \& Bickford, M.E. 2004: Thrusting and extension in the Scandinavian Caledonide hinterland, Norway: new $\mathrm{U}-\mathrm{Pb}$ ages and tectonostratigraphic evidence. American Journal of Science 304, 477-532.

https://doi.org/10.2475/ajs.304.6.477.

Uchman, A., Hanken, N.-M. \& Binns, R. 2005: Ordovician bathyal trace fossils from metasiliciclastics in central Norway and their sedimentological and paleogeographical implications. Ichnos 12, 105-133. https://doi.org/10.1080/10420940590914534.

van Staal, C.R. \& de Roo, J.R. 1995: Mid-Paleozoic tectonic evolution of the Appalachian Central Mobile Belt in northern New Brunswick, Canada: collision, extensional collapse and dextral transpression. Geological Association of Canada, Special Paper 41, 367-389. van Staal, C.R., Whalen, J.B., Valverde-Vaquero, P., Zagorevski, A. \& Rogers, N. 2009: Pre-Carboniferous episodic accretionrelated orogenesis along the Laurentian margin of the northern Appalachians. Geological Society, Special Publications 327, 271-316. https://doi.org/10.1144/SP327.13.

van Staal, C.R., Barr, S.M. \& Murphy, J.B. 2012: Provenance and tectonic evolution of Ganderia: constraints on the evolution of the Iapetus and Rheic oceans. Geology 40, 987-990.

Vogt, T. 1936: Orogenesis in the region of Paleozoic folding of Scandinavia and Spitsbergen. $16^{\text {th }}$ International Geological Congress, Washington, 1933. https://doi.org/10.1130/G33302.1.

Vogt, T. 1945: The geology of part of the Hølonda-Horg district, a type area in the Trondheim Region. Norsk Geologisk Tidsskrift 25, 449-528.

Waldron, J.W.F., Schofield, D.I., Dufrane, S.A., Floyd, J.D., Crowley, Q.G., Simonetti, A., Dokken, R.J. \& Pothier, H.D. 2014: GanderiaLaurentia collision in the Caledonides of Great Britain and Ireland. Journal of the Geological Society 171, 555-569. https://doi.org/10.1144/jgs2013-131.

Whalen, J.B., McNicoll, V.J., van Staal, C.R., Lissenberg, C.J., Longstaffe, F.J., Jenner, G.A. \& van Breeman, O. 2006: Spatial, temporal and geochemical characteristics of Silurian collision-zone magmatism, Newfoundland Appalachians: an example of a rapidly evolving magmatic system related to slab break-off. Lithos 89, 377404. https://doi.org/10.1016/j.lithos.2005.12.011.

Whitehouse, M.J., Kamber, B.S. \& Moorbath, S. 1999: Age significance of $\mathrm{U}-\mathrm{Th}-\mathrm{Pb}$ zircon data from early Archaean rocks of west Greenland - a reassessment based on combined ion-microscope and imaging studies. Chemical Geology 160, 201-224. https://doi.org/10.1016/S0009-2541(99)00066-2.

Wilson, R.A., van Staal, C.R. \& McClelland, W.C. 2015: Synaccretionary sedimentary and volcanic rocks in the Ordovician Tetagouche back-arc basin, New Brunswick, Canada: evidence for a transition from foredeep to forearc sedimentation. American Journal of Science 315, 958-1001. https://doi.org/10.2475/10.2015.03.

Wilson, R.A., van Staal, C.R. \& Kamo, S.L. 2017: Rapid transition from the Salinic to Acadian orogenic cycles in the northern Appalachian orogen: evidence from northern New Brunswick, Canada. American Journal of Science 317, 448-481. https://doi.org/10.2475/04.2017.02. 
